valley but its branches, would, according to Mr. Ellett, "probably form a lake covering from is to $r 8$ square milcs, with an average depth of nearly 30 feet, and containing more than $12,000,000,000$ cubic feet of water." "It follows then that we should need but four dams, such as we have described, to secure the valley of the Upper Ohio against all destructive floods.

This however assumes that at the beginning of a flood the reservoirs will be empty-a condition on which it would not be safe to rely. lit also seems that the shape of the valleys of the tributaries of the Ohio is everything that could be wished by an engineer who desired to convert them by means of dams into artificial lakes. They are trough-shaped, moderately wide, long, and not too stcep. This last is a great advantage, because the steeper the valley the shorter is the lake that will be formed by a dam across it. It is likely that the Garonne and its tributaries are less favourably circumstanced, but nevertheless in a country of such varied contour as the south-west of France, there must be many eligible sites for reservoirs. In another way also the Garonne will certainly be found a less manageable river than the Ohio, namely that the volume of its floods bears a much higher ratio to its erdinary flow.

After the disastrous floods of the Loire in 1855 , the late Emperor wrote a letter to his Minister of Public Works recommending the control of the fioods by means of a number of small reservoirs to be formed by building dams across the mountain valleys. This however was lost sight of, and we see the result in the ruins of Toulouse.

A most useful work of this kind has been in operation for many years in Ireland. The following particulars are taken from a paper " on the Industrial Uses of the Upper Bann River," by John Smyth, jun., C.E., read at the Belfast Meeting of the British Association last year, and ordered by the General Committee to be printed in extenso.

The purpose of the reservoirs on the Bann is not to prevent floods, which, so far as we are aware, wrere never particularly disastrons on that river, but to equalise the flow of the river for. water-power. "In I835 the principal millowners formed themselves into a provisional committee to take steps to procure a better and more regular supply of xater by the construction of reservoirs. They placed the matter in the hands of Sir William Fairbaim, who, assisted by J. F. Bateman, Esq., surveyed the collecting grounds of the river Bann and its several tributaries." Under their advice two reservoirs were constructed at Lough Island Reavy and Corbet Lough.

The Lough Island Reavy reservoir is 250 acres in extent, and contains $270,000,000$ cubic feet. It cost $15,000 l$. to construct, besides $6,000 \%$ for land. It is 430 feet above the sea-level, and is supplied by two mountain streams. Its drainage area, including the lake itself, is only about five square miles, and it is filled and emptied only once in the year.

The Corbet reservoir is lower down than the other, and is chiefly filled from the Bann itself. Its extent is 70 acres, and its capacity $28,000,000$ cubic feet. It "has been of much more service than its capacity would lead one to expect, as it may be filled and emptied four or five times in each year by small floods in the river, and all the Sunday water can be sent into it, and let down to the mills on Monday and Tuesday. It is generally exhausted before the upper reservoir is called on, and keeps up a supply when there is a scarcity in frosty weather."

The purpose of regulating the supply has been tolerably well attained. "A register of the daily height of the water in Lough Island Reavy has been kept since 1847 . It shows that this reservoir has been of great service, as during 26 years an average supplementary sipply of abour two-fifths of the standard summer discharge allowed over Ervin's Weir, or about 30 cubic feet per second, has been granted, for, on an average, Ioz days yearly: and the reservoir has been empty, on an average, eleven and a hail days yearly." "The rezister of the Corbet reservoir has not been kept so long or so accurately as that of Lough Island Reavy; from the average of three years, however, and comparison the register of Lough Island Reavy, I calculate it has given $120,000,000$ cubic feet in the year, exactly one half that of Lough Island Reavy, or a good supply for fifty-one days; add to this the Lough Island Reavy supply, and there is a total of I53 days of twenty-four bours each." "As the supply from the reservoirs has only failed, on an average, eleven and a half days yearly, the standard water power may be said to have been almost constantly maintained :indeed it is almost as good as steam-power; but at much less cost."

The income of the Company which has made the reservoirs is derived from a charge autborised by their Act of Pariament of $10 l$ ner annum per foot of fall occupied by manufactories, and half of this when occupied by flax scutching mills and country com-mills. The total fall from the upper reservoir to the bottom of the lowest fall is 350 feet, of which I 80 are occupied by machinery. The capital of the Company is 31,000l., and the dividend about three per cent, with a certainty of increase, if the advance in the price of cools, and the expected opening of the higher part of the district by railway, lead to more of the falls being occupied.

We think the calculations we have quoted from the American engineer, and the example of what has been done on a comparatively small scale in Ireland, are enough to show that the most difficult problems of the regulation of the flow of rivers may be approached with great hope of success.

\section{THE GIGANTIC LAND TORTOISES OF THE} MASCARENE AND GALAPAGOS ISLANDS*

\section{II}

ATHOUGH the island of Aldabra is a British posA session, its distarice from the Mauritius and the Seychelles renders a supervision on the part of the Government very difficult, and no control whatever can be exercised on crews of ships who land there chiefly for the purpose of cutting wood, which they require for curing fish, \&c. Information having reached England in the course of last year that it was intended to lodge permanently wood-cuting parties on the island, the speedy extinction of the tortoises seemed imminent; and the time to prevent this seemed all the more opportune, as the then Governor of the Mauritius, Sir Arthur Gordon. was known to take great interest in all matters relating to natural history. Consequently the following memorial was addressed to him, signed by the presidents of the Royal and Royal Geographical Societies, and other men of science who had made researches into the extinct fauna of these islands :-

To His Excellency the Hon. Sir Arithr Hamilton Gordon, K.C.M.G., Governor and Commander-in-Chief of Mauritius and its dependencies.

We, the undersigned, respectfully beg to call the attention of the Colonial Government of Mauritius to the imminent extermination of the Gigantic Land Tortoises of the Mascareries, commonly called "Indian Tortoises."

2. These animals were formerly abundant in the Mauritius, Réunion, Rodriguez, and perhaps other islands of the western part of the Indian Ocean. Being highly esteemed as food, easy of capture and transport, they formed for many years a staple supply to ships touching at those islands for refreshment.

* The substance of this article is contained in a paper read by the author before the Royal Society in Jun. I87a, which will appear in the author before the Royal Society in June, 1874 , which will appear in the forthcoming volume of the "Philosophicil Transactions," and to which must refer for the scientic portion and other details. Some facts which have come to my knowledge subsequently to the reading of this paper. are added. Continued from p. 239. 
3. No means being taken for their protection, they have become extinct in nearly all the-e islands, and Aldabra is now the only locality where the ias remains of this animal form are known now to exist in a state of nature.

4. We have been informed that the Government of Mauritius have granted a concession of Aldabra to parties who intend to cut the timber on this island. If this project be carried out, or if otherwise the island is occupied, it is to be feared, nay certain, that all the tortoises remaining in this limited area will be destroyed by the workmen employed.

5. We would, therefore, earnestly submit it to the consideration of Your Excellency whether it would not be practicable that the Government of Mauritius should cause as many of these animals as possible to be collected before the wood-cutting parties or others land, with the view of their being transferred to the Mauritiu; or the Seychelle Islands, where they might be depo. sited in some enclosed ground or park belonging to the Govern. ment, and protected as property of the Colony.

6. In support of the statements above made and the plan now submitted to the Mauritius Government, the following passages may be quoted from Grant's "History of Mauritius" (I80I, 4to.):-

"We (in Mauritius) possess a great abundance of both land and sea turtle, which are not only a great resource for the supply of our ordinary wants, but serve to barter with the crews of ships" (p. 194).

"The best production of Rodriguez is the land-turtle, which is in great abundance. Small vessels are constantly employed in transporting them by thousands to the Isle of Mauritius for the service of the hospital " (p. IOO).

"The principal point of view (in Rodriguez) is, first, the French Govemor's house, or rather that of the Superintendent, appointed by the Governor of the Isle of France, to direct the cultivation of the gardens there and to overlook the park of land-turtles. Secondly, the park of land-turtles, which is on the sea-shore facing the house." (p. Ior.)

7. The rescue and protection of these animals is, however, recommended to the Colonial Government less on account of their utility (which nowadays might be questioned in consideration of their diminished number, reduced size, and slow growth, and of the greatiy improved system of provisioning ships which renders the crews independent of such casual assistance), than on account of the great scientific interest attached to them. With the exception of a similar tortoise in the Galapagos Islands (now also fast disappearing), that of the Mascarenes is the only surviving link reminding us of those still more gigantic forms which once inhabited the Continent of India in a past geological age. It is one of the few remnants of a curious group of animals once existing on a large submerged continent, of which the Mascarenes formed the highest points.

It flourished with the Dodo and Solitaire, and whilst it is a matter of lasting regret that not even a few individuals of these curious birds should have had a chance of surviving the lawless and disturbed condition of past centuries, it is confidently hoped that the present Government and people who support the "Natural History Society of Mauritius" will find the means of saving the last examples of a contemporary of the Dodo and Solitaire.

Loudon, April i 874

$$
\text { [Hree follow the signatures.] }
$$

This memorial was most favourably received by $\operatorname{Sir} A$. Gordon, who in his reply states that, although the intention of conceding the island to parties for the purpose of cutting wood had not yet actually been carried out, the extermination of the tortoises is proceeding quite as rapidly as if this were the case. Not only are the animals destroyed by the whalers, but (as he was informed by visitors to the island) the pigs, which are supposed to have been left there by a passing ship some years ago, and which have rapidly multiplied, turn up the eggs in great numbers, and even devour the very young tortoises. The lessee should be bound to protect the animals and to remit annually to Mauritius a pair of living ones which, with others acquired by purchase, would be preserved in a paddock of the Botanic Gardens at Pamplemousses. He adds that in several of the Seychelle Islands such paddocks exist, the young tortoises being esteemed as articles of food; at four years they appear to be considered fit for eating; but he never observed that any are allowed to grow up as breeding stock to replace the original pair.
We confidently hope that Sir A. Gordon's successor will not lose sight of this matter and that the Royal Society of Arts and Sciences of Mauritius, to whom a copy of the memorial has been sent, with the request to support the appeal of their fellow-labourers in England, will recognise it as one of their duties to watch that the existence of one of the most interesting animal types within the limits of their own special domain, is not only prolonged but insured for all times.

We owe it chiefly to the kind mediation of Sir A. Gordon that a living pair of the Aldabra Tortoises are at present in London. Anxious to acquire this pair for the collection of the British Museum, the male being known to be the finest individual of the species in existence, I requested Sir A. Gordon to assist me in their acquisition, the owner being at first reluctant to part with them. To the excellent arrangements of the Hon, C. S. Salmon, Chiet Commissioner of the Seychelles, and to the most fortu. nate circumstance that Dr. Brooks, the Government Inedical Officer, accompanied and took charge of the animals on their journey to Europe, we have to thank that they arrived in the most perfect state of health. The Zoological Garden being clearly the most appropriate place for them during their lifetime, I handed them over to the Zoo!ogical Society, and have no doubt that, with the interest taken in this subject by Mr. Sclater, and with the care bestowed on them by Mr. Bartect, these animais have a better chance of surviving their transmission into our severe climate than the specimens imported some thirty or forty years ago.* Mr. Salmon writes that both the tortoises are ratives of Aldabra, though not of the same breed. The larger, the male, has been in the Seychelles for about seventy years; its last proprietor, M. Deny Calais, kept it with the female in a semidomesticated state on Cerf Island. His weight is about 800 lbs. ; the length of the shell $5 \mathrm{ft}$. $5 \mathrm{in}$. (in a straight line), the width $5 \mathrm{ft} .9$ in.; + circumference of the shell, $8 \mathrm{ft}$ I in.; circumference of fore leg, I ft. I I in., and of hind leg, $1 \mathrm{ft} .6$ in. ; length of head and neck, $x$ tt. 9 in. ; width of head, $6 \mathrm{in}$. The female is much smaller, and $I$ have no information as regards the time she was brought to the Seychelles. The length of her shell is $3 \mathrm{ft} .4 \mathrm{in}$., the width $3 \mathrm{ft}$. Io in., the circumference $5 \mathrm{ft}$. 4 in. She lays thrice every year, in the months of July, August, and September, each time from fifteen to twenty round hardshelled eggs. There is every reason to believe that the laying of eggs will not be interrupted by the transmission of the animals to England.

Every one who sees these two tortoises side by side is at once struck by the great difference in form and sculpture of the shell. That of the male is remarkably high, with a rounded outline, each plate being raised into a hummock, and deeply sculptured with concentric furrows along the margins. The female, on the other hand, has a perfectly smooth shell with an oval outline, without either furrows or raised portions. The shell of the male is brownish, that of the female black. The male has also a comparatively longer neck and tail than the female. It is quite possible that these are sexual differences, the males being known to grow to a much larger size than the females. But as Aldabra consists of three islands, separated by channels of the sea which are impassable barriers to animals which may float but cannot swim, it may be presumed that the two animals come from distinct islands, each island of the group being inhabited by a distinct race, as in the Galapagos. This is a question

* I have kept young specimens of the Aldabra Tortoise (two of which are the offspring of the very individuals now imported), as well as half-grown ones of the Galapasos species, for years. Want of water and a twenty-four hours' exposure to a temperature below $50^{\circ}$ are fatal to them. In the autumn and winter they must be kept in a greenhouse where the tempera. ture should be kept at about $70^{\circ}$. With a plentiful and varied supply of vegetables, they thrive well and grow perceptibly.

$\dagger$ A large example, probably of the Rodriguez species, which formerly lived in the Zoclogical Gardens, and is described in Proc. Zool. Soc., I833, p. $8 x$, weighed 289 lbs., the shell being 4 ff. 4 hit. in lengh (oyer the curys), and aft. $g$ in, in widtha. 
the investigation of which I would particularly recommend to persons visiting Aldabra.

Mr. Salmon states that the male shows himself to be annoyed when the female is disturbed, and there is no doubt that he exhibits affection for her, as was especially evident on board the steamer, when he tried to break out of his cage as soon as he got sight of the female, who was transported in a separate cage. The circumstance that the two animals are a pair, increases the chances in favour of their being kept alive for a lengthened period. And they will be well worth all the care we can bestow on them, as it is extremely doubtful whether we shall ever succeed again in obtaining a pair of full-grown examples. The male is without doubt the largest and most powerful individual of its race, far exceeding in size any of the few other individuals kept in the Seychelles. Nor is it likely that in Aldabra itself a similarly large example should have succeeded in evading the search of the numerous crews which have landed there.

From the historical evidence given above, it is evident:

I. That the presence of the Gigantic Tortoises at two so distant stations as the Galapagos and Mascarenes cannot be accounted for by the agency of man, and therefore that these animals must be regarded as indigenous.

2. That, although frequently transported by the early navigators to distant and apparently suitable localities (Sandwich Islands, Masa Fuero, and Ceylon), they never established themselves permanently, but there is no evidence to show whether this failure is due to an innate inability of the species to become acclimatised when far removed from its native place, or to the destructiveness of the inhabitants of those localities.

3. That the different islands of the Galapagos group were inhabited by distinct races.

4. That possibly the animals even of so small a group as Aldabra were differentiated in the different islands.

5. That although these animals are still lingering in the Galapagos and Aldabra their numbers are yearly diminishing, and that their growth to perfect maturity is interrupted; that with respect to the races of the Galapagos Tortoise, the elucidation of the irdistinctive characters and original distribution, we are, and probably shall be, dependent chiefly on the materials already preserved in zoological museums.

6. That the Tortoises of Mauritius and Rodriguez are entirely extinct. It is probable that in some museums shells, or even entire animals of these once so numerous races exist, but it will be a matter of great difficulty to trace their origin; therefore our examination is limited at present to the osseous remains transmitted from the Mauritius and Rodriguez.

(To be continued)

\section{NOTES}

Wis are glad to hear that both a zoological and botanical collector will form part of the retinue of the Prince of Wales, in his approaching visit to India.

DR. VOGEL (not the photographer of that name), the Director of the newly established "Sonnenwarte" of Berlin, is now in this country.

THE rate of propagation of the recent inundation waves in the south of France has been determined along the banks of the Gatonne. It was found to have been no more than two miles an hour in a run of 140 miles in the district where the principal calamities occurred. The consequence is that an immense amount of property and life could have been saved if a system of warnings had been adopted. Wise as usual after the event, the authorities intend to establish such a system as is already in operation at Lyons for the Rhône, and at Paris for the Seine. In an article in the July number of Symons's Monthly Meteorological Magazine, on the French floods, is an interesting calculation which will give Londoners some idea of what a "flood" means, Sup. posing we had a flood in the Thames, it would cover on the south bank, the whole of Battersea Park, Lambeth, Southwark, Bermondsey, and Deptford; and on the north bank, Fulham, Chelsea, Brompton, Belgravia, Westminster, and St. James's Park; while, as for the new embankment, a steamer might ply over the top of it.

IT is suggested that the unusual violence of the floods on the continent are attributable not only to the abnormal amount of rain and the sudjen melting of snow and ice in the mountain districts, but also to the increasing destruction of forests which is taking place in nearly every country. For some years past the violence of the spring and summer floods has been increasing, and it is remarkable that this increase in their force is contemporaneous with the gradual extinction of forests and woodlands. The existence of forests has a great effect in equalising the distribution of water, and in checking the too rapid melting of snow and ice under the influence of the summer heat. At the same time the growth of timber on hill sides prevents the rapid flow of surface-water which takes place where trees do not exist. The question of maintaining forests, instead of destroying them, without making provision for the future, is one which demands the serious attention of the governments of every country, and particularly of those countries where, by the existence of hills and mountains, and consequently rapid rivers, the liability to floods is increased.

We have been informed that during the recent very bad weather there has been an unusual number of icebergs met with in the North Atlantic, and that fogs in Labrador and New. foundland have been extraordinarily severe and frequent. It is to be hoped that some general inquiry into the recent peculiar weather and its accompaniments will be instituted; no doubt valuable results would be obtained.

THE Austrian Commission to the International Geographical Exhlbition has intimated that they intend to present to the French Geographical Society all the books they are exhibiting. As this example will, we are informed, be followed by other Commissions, a magnificent Geographical Library will be one of the results of the meeting of the Congress.

THE work of the SuD-Wealden Exploration is temporarily arrested at 1,672 feet from increasing deposit from the sandy beds. The original problem was dependent on the opinion of geologists that paleozoic rocks would be found at a depth vary. ing from 700 to $x, 700$ feet. So far, however, the strata are mesozoic; but the latest fossils give some indications of a palæozoic rock. Much hope is therefore entertained of solving the problem.

PARTS I9 to 24 of the quarto work published by authority of the Lords Commissioners of the Admiraity, on the Zoology of the Voyage of H.M.S. Erebus and Terror, conclude the descriptions of the Mammalia by the Jate Dr. J. E. Gray, F.R.S. ; the Birds by Mr. R. B. Sharpe; the Reptiles by Dr. A. Günther, F.R.S. ; and the Insecta by Mr. A. G. Butler. Part 20 is by Mr. E. J. Miers on the Crustacea, and Part 2 I by Mr. E. A. Smith on the Mollusca.

THE Rev. E. Ledger, M.A., rector of Duxford, Cambridgeshire, was yesterday elected to the Gresham Professorship of Astronomy in the City of London. Mr. Ledger was a Carpenter and Beaufoy Scholar of the City of London School, and afterwards Fellow and Lecturer of Corpus Christi College, Cambridge. He was fourth Wrangler in 1863, and also University Scholar of the University of London.

AN International Horticultural Exhibition and Congress is to be held in Amsterdam in 1876, similar to the one held in Florence last year. A strong committee has been appointed, 